Yeshiva University, Cardozo School of Law

LARC @ Cardozo Law

Articles

Faculty

Winter 1976

\title{
Indian Water Rights in Theory and Practice: Navajo Experience in the Colorado River Basin
}

Monroe E. Price

Benjamin N. Cardozo School of Law, price@yu.edu

Gary D. Weatherford

Follow this and additional works at: https://larc.cardozo.yu.edu/faculty-articles

Part of the Law Commons

\section{Recommended Citation}

Monroe E. Price \& Gary D. Weatherford, Indian Water Rights in Theory and Practice: Navajo Experience in the Colorado River Basin, 40 Law and Contemporary Problems 97 (1976).

Available at: https://larc.cardozo.yu.edu/faculty-articles/378

This Article is brought to you for free and open access by the Faculty at LARC @ Cardozo Law. It has been accepted for inclusion in Articles by an authorized administrator of LARC @ Cardozo Law. For more information, please contact larc@yu.edu. 


\title{
INDIAN WATER RIGHTS IN THEORY AND PRACTICE: NAVAJO EXPERIENCE IN THE COLORADO RIVER BASIN*
}

\author{
Monroe E. Price $\dagger$ \\ GARY D. WEATHERFORD $\dagger \dagger$
}

\begin{abstract}
Although Indian water rights are of critical economic importance, the nature and scope of these rights remain unclear. The Supreme Court has addressed itself to the issue infrequently, and most commentators have limited their discussions to an exegesis of the appellate arguments rather than engage in an analysis of the broader nature and context of these rights. Reservation water rights are of a very special nature: A right to water does not necessarily include a right to the capital investment necessary to realize the economic benefit of an entitlement, and limits on the uses of the water may be at odds with the original purposes of the reservation. ${ }^{1}$ Because of recent and forthcoming federal legislation, ${ }^{2}$ state unilateral action, and judicial decisions $^{3}$ on these questions, it is essential to understand how the Indians have
\end{abstract}

\footnotetext{
* Research for this article was supported by Grant No. NSF GL 34833 to the Legal-Institutional Subproject, and by Grant No. NSF 34832 to the Anthropology Subproject, of the Lake Powell Research Project from the Division of Environmental Systems and Resources of RANN (Research Applied to National Needs) in the National Science Foundation. Any opinions, findings, conclusions or recommendations expressed in this publication are those of the authors and do not necessarily reflect the views of the National Science Foundation. Invaluable research assistance was provided by John R. McCain, Political Science graduate student and Ph.D. candidate, University of Arizona, and Richard Conn, law student at the U.C.L.A. School of Law.

$\dagger$ Professor, School of Law, U.C.L.A.

$\dagger \dagger$ Member, California Bar. Since this manuscript was submitted before Mr. Weatherford became Deputy Secretary for Resources, State of California, the views expressed herein are his own and do not necessarily represent those of his new employer.

1. For the argument that Winters doctrine rights may be applied to non-agricultural uses, see Leaphart, Sale and Lease of Indian Water Rights, 33 Mont. L. Rev. 266, 275 (1972); Ranquist, The Effect of Changes in Place and Nature of Use of Indian Rights to Water Reserved Under the "Winters Doctrine," 5 NAT. Res. L. 34, 37 (1971); Sondheim \& Alexander, Federal Indian Water Rights: A Retrogression to Quasi-Riparianism?, 34 S. CAL. L. REv. 1 (1960); Veeder, Winters Doctrine RightsKeystone of National Program for Western Land and Water Conservation and Utilization, 26 MoNT. L. REv. 149, 170 (1965).

2. See recommendation for a "National Water Rights Procedure Act": and an Indian water rights act, in National Water Comm'n, Water Policies for the Future 461-71, 477-83 (1973), detailing legislative proposals geared toward quantification of Indian water rights. See also S. 3298, 94th Cong., 1st Sess. (1976) (settlement of the water rights of the five Central Arizona Indian Tribes and providing for water projects which would permit those Indian groups to exercise their water rights).

3. Of particular importance is the decision in Colorado River Water Conservation Dist. v. United States, 96 S. C.t. 1236 (1976) which held that the McCarran Amendment, 43 U.S.C. $\$ 666$ (1970), permits the determination in state court of reserved water rights held by the United States on behalf of Indians.
} 
had to bargain over their legal rights in the face of limited economic alternatives and the consequent difficulties that have been posed for implementation.

One of the most interesting contemporary opportunities to study the interplay between the definition and implementation of economic rights of an Indian reservation is provided by the experience of the Navajo tribe during the 1960s. The construction of Glen Canyon dam and Lake Powell has made possible major power projects requiring substantial use of water. To secure water for these uses, it was necessary to determine the extent to which the Navajo Reservation would share in the benefits of the river and its tributaries. The procurement of water rights to be used in the Navajo Generating Station at Page, Arizona became a vehicle for bargaining over the extent of Navajo entitlement to Colorado River water. In addition, the history of the Navajo Indian Irrigation Project provides an extraordinary opportunity to assess the difficulties involved in implementing a right once defined and bargained for in the context of a reservation dependent on federal largess for the financing of large-scale development.

Close scrutiny of these major incidents in the definition of economic rights on the Navajo reservation is important because of underlying assumptions about the status of Indian reservations and federal and tribal policy toward economic and cultural self-sufficiency. Since the nineteenth century, a basic principle of fundamental fairness in dealing with indigenous people in the United States has been the insulation of reservation resources from the constraints of the marketplace, ${ }^{4}$. state taxation, ${ }^{5}$ and state jurisdiction ${ }^{6}$ at least until the Indian communities living on those lands are socially and culturally prepared fully to exploit those resources. ${ }^{7}$ The growth of the guardianward ideal, buttressed by the concept of Indian tribal sovereignty, suggests that reservation lands were not subject to the laws of the states with respect to resource allocation. Yet at different times and places the principle of reservation insulation gave way to other forces, primarily the unyielding need

4. See Johnson v. McIntosh, 21 U.S. (8 Wheat.) 542 (1823).

5. See, e.g., The Kansas Indians, 72 U.S. (5 Wall.) 737 (1867), holding that, at least absent congressional consent, Kansas could not impose a property tax upon Indian lands. See also N. Margold's 1940 solicitor's opinion. Margold, Indians Not Taxed-Interpretation of Constitutional Provisions, 57 Interior Dec. 195 (1940).

6. Worcester v. Georgia, 31 U.S. (6 Pet.) 515 (1832).

7. In United States v. Clapox, 35 F. 575, 577 (9th Cir. 1888), Judge Deady based the reservation concept upon an educational function: "In fact, the reservation itself is in the nature of a school, and the Indians are gathered there . . . for the purpose of acquiring the habits, ideas, and aspirations which distinguish the civilized from the uncivilized man." The consequences of this view are explored in M. Price, Law and the American Indian 88-89 (1973). The rehabilitation strategy was reiterated in Winters v. United States, 207 U.S. 564, 576 (1908), where the Supreme Court explicitly recognized an early government policy aimed at changing the stereo-Indian lifestyle, of altering the "habits and wants of a nomadic and uncivilized people" in order to engender "a pastoral and civilized people." 
of the settler community and their abundant descendants to utilize the reserved resources themselves. In the nineteenth century, this territorial imperative was reflected in the removal policy, ${ }^{8}$ and later in the breaking up of reservations through the Indian General Allotment Act $^{9}$ and transformation of the Indian Territory into modern states. ${ }^{10}$ In the twentieth century, the conflict between the reservation theory and the demand for resources has sometimes been more subtle, and nowhere is this conflict more intense than in the struggle for the waters of the Colorado River in the semiarid Southwest.

To situate the present conflict over Indian rights, it is important to understand the legislative and hydrological context of water distribution in the Colorado River. ${ }^{11}$ The first Colorado River Compact, ${ }^{12}$ drafted in 1922, had as its objective the apportionment of the Colorado River System ${ }^{13}$ between the hydrologically defined Upper and Lower Basins of the river. ${ }^{14}$ This was achieved when all of the basin states agreed that, of the estimated sixteen million acre-feet average annual flow of the river, ${ }^{15}$ the Upper and Lower Basin each had the right to the beneficial consumptive use of 7.5 million acre-feet, and the Lower Basin had the additional right to increase its beneficial consumptive use by one million acre-feet annually. The 1922 Compact thus served to apportion the average flow of the river between the Upper and Lower Basins, rather than among individual states. However, since not all of the boundaries of basin states correspond with the hydrologically drawn division between the Upper and Lower Basins, several states, including Arizona, have lands in both the Upper and Lower Basins. It is of great consequence for the present discussion, therefore, that almost all of Arizona's lands within the Upper Basin are within the boundaries of the Navajo Reservation.

8. See generally G. Foreman, Indian Removal (1932).

9. Indian General Allotment Act of 1887, ch. 119, 24 Stat. 288, as amended, 25 U.S.C. \& 331 (1970). It has been estimated that during the interval spanning the passage of the Act and 1934, when the allotment process was largely halted, tribal landholdings were reduced from approximately 138 million acres to about 48 million acres. See W. Brophy \& S. Aberle, The Indian, AMErica's Unfinished Business 20 (1966).

10. See, e.g., A. Debo, The Rise and Fall of the Choctaw Republic 269 (2d ed. 1967).

11. A significant aid to that understanding is Meyers, The Colorado River, 19 Stan. L. Rev. 1 (1966).

12. The Colorado River Compact, 70 Cong. Rec. 324 (1928), consented to by Congress in the Boulder Canyon Project Act, 43 U.S.C. $\$ 617(1)$ (1970), was made effective by presidential proclamation June 25, 1929, 46 Stat. 3000.

13. The Colorado River "system" is defined in article II(a) of the Compact as "that portion of the Colorado River and its tributaries within the United States." Colorado River Compact, art. II(a), 70 CoNG. Rec. 324 (1928).

14. The Upper Basin is comprised of lands from which water drains into the mainstream above Lee Ferry, Arizona; the Lower Basin lands drain into the mainstream below this point.

15. This estimate, based on unusually high flows in the years immediately preceding 1922 , is approximately two million acre-feet per year higher than what is currently believed to be the average annual flow. See Weatherford \& Jacoby, Impact of Energy Development on the Law of the Colorado River, 15 Nat. Res. J. 171, 183 table 1 (1975). 
The second interstate compact affecting the law of the river is the Upper Colorado River Basin Compact of 1948. ${ }^{16}$ This agreement elaborates on the 1922 Compact by apportioning the waters of the Upper Basin among the individual states involved. ${ }^{17}$ States asserting rights under this apportionment scheme must have a beneficial use for a corresponding amount of water. Thus, the apportionment of the 1948 Compact in no case gives a state the right to divert water it cannot use, or to prevent another state from beneficially using such water.

The 1948 Compact thus appears to effect a final and comprehensive apportionment of Upper Basin waters. But the Upper Basin Compact also provides that "[n]othing in this Compact shall be construed as: (a) Affecting the obligations of the United States of America to Indian tribes."18 The agreement, however, was only among the states; the affected reservations were not invited to the bargaining table. It was not determined how extensive the Indian rights were or against which state's apportionment they should be charged. Clearly the states acting alone could not agree to a diminution of Navajo rights. Navajo rights could, of course, be charged against the Arizona entitlement. But if the Navajos have a right in excess of Arizona's share, the effect would be to alter the apportionments of all other Upper Basin states. It is that legal possibility that came to be of significance in the 1960s.

In order to understand the nature and implications of competing claims to the waters of the Colorado River, it is particularly important to understand how the uncertainties of existing water law have forced tribes like the Navajo to bargain over their apparent rights in an attempt to achieve greater economic security. Indeed, a realistic assessment of the Indian's legal rights would be incomplete without an appreciation of why, under present circumstances, the implementation of bargained-for rights, though economically advantageous, may be achieved at the cost of weakening the political and cultural integrity of the tribe. It is in this complex interaction of social, economic, and political factors that an understanding of the legal concept of Indian water rights must necessarily be sought.

16. Act of April 6, 1949, ch. 48, 63 Stat. 31.

17. The Upper Colorado River Basin Compact, Act of April 6, 1949, ch. 48, art. III, § 2, 63 Stat. 31, grants Arizona 50,000 acre-feet per year of water. The balance was divided among the remaining states in the following proportions: Colorado 51.75 per cent, New Mexico 11.25 per cent, Utah 23.00 per cent, and Wyoming 14.00 per cent.

18. Id. art. XIX, 63 Stat. 42. Identical language can be found in its predecessor, Colorado River Compact, art VII, 70 Cong. Rec. 324, 325 (1928). The clause might easily be construed as "a negative declaration to the effect that Indian rights are outside the reach of the interstate accord." Weatherford \& Jacoby, supra note 15, at 179. However, the specificity of the state apportionments allocated by the Compact, as well as its directive that those apportionments are to be charged with Indian uses, suggest that that construction is by no means free from doubt. See R. Conn, Tribal Water Rights and the Navajo Generating Plant: An Analysis of Legal Issues 8-9, 1974 (unpublished manuscript on file with Professor Price).

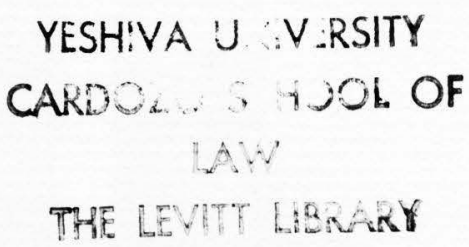




\section{The Winters Doctrine Revisited: RightS AND UNCERTAINTIES}

Indian water rights are to the late twentieth century what Indian land rights were to the nineteenth, and many of the same utilitarian arguments applied to the scarcity of land have been applied to water in the last several decades. ${ }^{19}$ The question often becomes not who owns the water but how can it best be used: for the reservations and their relatively few inhabitants or for the industrial metropolises of the Southwest. ${ }^{20}$ Water rights are as critical for Indian well-being and development now as land rights were in the late nineteenth century. ${ }^{21}$ But as with land, Congress has assumed enormous powers in the definition of Indian rights to water. ${ }^{22}$ And the pressures and techniques to encourage Indian consent to the modification of Indian water rights are strikingly reminiscent of practices in the nineteenth century.

\section{A. The Issue of Quantum}

A sharp contrast exists between the water law that has developed in the western states and on the Indian lands. Under the western doctrine of "prior

19. The arguments are directed toward a common theme-the use of a limited and hence valuable resource-and reflect a common pattern. In assessing the validity of a 1908 agreement between the federal government and non-Indian landowners, which allocated 75 per cent of the flow of Ahtanum Creek to the latter and 25 per cent to the Yakima Indians, the Court of Appeals for the Ninth Circuit mirrored that pattern by briefly reviewing the history of federal dealings with the American Indian:

That history largely supports the statement: "From the very beginnings of this nation, the chief issue around which federal Indian policy has revolved has been, not how to assimilate the Indian nations whose lands we usurped, but how best to transfer Indian lands and resources to non-Indians."

United States v. Ahtanum Irrigation Dist., 236 F.2d 321, 337 (9th Cir. 1956).

20. The question is not a novel one. Underlying the legal contentions pressed by the nonIndian users in Winters v. United States, 207 U.S. 564 (1908), was the equitable claim that recognition of an implicitly reserved Indian right to water would ultimately destroy established Montana communities dependent upon the continued diversion of water from the Milk River. The tremendous amplification simply in the number of competing interests occasioned by the urban explosions that have occurred in the Southwest since the Winters decision adds to the difficulty of resolving the question of how a finite water resource can best be utilized.

The urban-based "environmentalist" and "recreationist" demands clean water. The urban "voter" demands that limits be put on subsidies for agricultural development (while insisting upon low food prices). The urban "consumer" sustains a high-energy lifestyle which sends the electric utilities to the banks of the Colorado in search of powerplant sites. These often times inconsistent demands add up to an urban assault of major proportions on the rural reclamation ethic.

Weatherford \& Jacoby, supra note 15 , at 174

21. "Seize and take from the Indian people, by whatever means, their life-sustaining Winters doctrine rights to water and you take from them the basis for their continued existence as a separate and distinct people." Veeder, Indian Water Rights in the Upper Missouri River Basin, 48 N.D.L. Rev. 617, 618 (1972). See also Young, Interagency Conflicts of Interests: The Peril to Indian Water Rights, 1972 Law \& Social Order 313.

22. 25 U.S.C. $\S 564$ (1970). 
appropriation," one may assert title to a specified quantity of water only as long as actual, beneficial use is made of that water. ${ }^{23}$ Moreover, in times of shortage, a senior appropriator's right is satisfied in full before the junior appropriator obtains his share. It is a harsh, pragmatic, pioneer doctrine firmly rooted in the concept of present beneficial use.

By contrast, Indian water rights depend on future need rather than on present use. It was in Winters $v$. United States ${ }^{24}$ that this right was first enunciated, and it is from this decision that many of the ambiguities of Indian water rights stem. In granting an injunction barring non-Indian users from interfering with the flow of the Milk River to the Fort Belknap Reservation, the Court held that, though the treaty establishing the reservation was silent as to water rights, the government's reservation of lands for the Indians implicitly carried with it a reservation of the water needed to make these lands "adequate and valuable" for their inhabitants. The Court further asserted that the rights of the Indians to such waters could not be diminished by application of state law. ${ }^{25}$ However, the parties did not argue, and the Court did not decide, the precise standard for measuring the quantity of water reserved, and subsequent courts have not been able to agree on such a standard. ${ }^{26}$

The enormous implications of Winters and its potential for conflict between Indian and non-Indian users were highlighted when the issue was presented again in Arizona $\%$. California. ${ }^{27}$ Adopting the Master's finding that the tribes involved had a valid claim to about one million acre-feet annually ${ }^{28}$ of the Lower Colorado River, the Court, reaffirming the reasoning in Winters, held that the United States "intended to deal fairly with the Indians by reserving for them the waters without which their lands would have been useless." 29 This reservation was necessary because economic competition for water, at that time, would have been ruinous.

Despite its support of Winters, Arizona \%. California did not necessarily eliminate uncertainty concerning its meaning. First, there is the issue of quantum. Quantum (when coupled with priority) determines the strength of the Indian bargaining position with private or public agencies. The literature

23. Arizona v. California, 373 U.S. 546, 555 (1963); Tweedy v. Texas Co., 286 F. Supp. 383, 385 (D. Mont. 1968). See generally Veeder, supra note 1.

24. 207 U.S. 564.

25. "The power of the Government to reserve the waters and exempt them from appropriation under the state laws is not denied, and could not be." Winters v. United States, 207 U.S. at 577.

26. United States v. Ahtanum Irrigation Dist., 236 F.2d at 321 ;'United States v. Walker River Irrigation Dist., 104 F.2d 334 (9th Cir. 1939); Conrad Investment Co. v. United States, 161 F. 829 (9th Cir. 1908).

27. 373 U.S. 546 .

28. Actually the decree authorized one million acre-feet or that amount of water sufficient to irrigate the practicably irrigable acreage, whichever was less.

29. 373 U.S. at 600. See also M. PRICE, supra note 7, at 316-18, discussing Arizona v. California and quoting, id. at 317 from RePort of the Special MASter in Arizona v. California 259 (1960). 
abounds with the assertion that Winters implies the existence of automatically reserved water rights on Indian reservations and everywhere demands the same quantum test in determining how much water was reserved. ${ }^{30} \mathrm{~A}$ close reading of the cases suggests that so clear and simple a definition of the Winters rights is not necessarily accurate. Under the Winters doctrine, "the basic question for determination was one of intent-whether the waters of the stream were intended to be reserved for the use of the Indians, or whether the lands only were reserved." ${ }^{31}$ What is the exact holding of Arizona $v$. California with respect to quantum? The Supreme Court's definition of the Master's finding was that the water reserved "was intended to satisfy the future as well as the present needs of the Indian Reservations [and that] enough water was reserved to irrigate all the practicably irrigable acreage on the reservations. $^{32}$ In answer to Arizona's contention that the quantum standard should be fixed by the number of Indians, the court stated that "[h]ow many Indians there will be and what their future needs will be can only be guessed. We have concluded . . . that the only feasible and fair way by which reserved water for the reservations can be measured is irrigable acreage."33 But the Court stopped short of making the irrigable acreage standard a universal and timeless test. ${ }^{34}$

The uncertainty of standard is also linked to the kind of decree a court will write as a result of its application. If the standard is one of potential irrigable acreage or future population, non-Indian water users will be unable to develop precise plans. ${ }^{35}$ If the standard is calibrated on the basis of the

30. See, e.g., Veeder, supra note 1.

31. United States v. Walker River Irrigation Dist., 104 F.2d at 336. Furthermore, the courts seem guided by the traditional principle that "treaties with the Indians and statutes disposing of property for that benefit have uniformly been given a liberal interpretation favorable to the Indian wards." 104 F.2d at 337. However, an intent must still be discovered, and all intents need not be the same. If intent, rather than a general rule of law, is the basis for Winters, each case must be looked at separately to determine the quantum standard. $C f$. Cappaert v. United States, 44 U.S.L.W. 4756,4759 (1976).

32. Arizona v. California, 373 U.S. at 600.

33. 373 U.S. at 601.

34. Indeed, the few words of the Court are themselves unsatisfactory. It is certainly true that the future Indian populations on the reservation "can only be guessed." But the number can be guessed with some range of accuracy, probably enough to use in fashioning a decree. As to the second part of the Court's modesty, its inability to define "what their future needs might be," the Court was merely begging the question. For as the cases and discussions of the Indian water right indicate, the critical issue involves the identification of those "future needs" that must be satisfied from the reserved rights.

35. A study by Sondheim and Alexander indicated that the amount of water reserved under an irrigable acreage test would often be many times the amount of water reserved under a test which was based on current usage and Indian population trends. Sondheim \& Alexander, supra note 1 , at 23. In one case, for example, the irrigable acreage on the Walker River Paiute Reservation was approximately ten thousand acres; the acreage actually cultivated was 2,100. United States v. Walker River Irrigation Dist., 104 F.2d 334. Almost five times as much water would be reserved under the Arizona $v$. California irrigable acreage standard. As Sondheim and Alexander put it, rather dramatically, "we are dealing with a problem where choice of a legal 
amount of water needed by a stabilized population to continue cultivation of their lands, ${ }^{36}$ no leeway will exist for increases in population. And if the order implementing a given standard is modifiable ${ }^{37}$ or seeks to achieve finality, ${ }^{38}$ it will partake of the same uncertainty or rigidity. It may be argued that the Arizona Court did not hold that the tribes had a perfected right to the flow measured by irrigable acreage, but rather that the Court was unable to determine a better method for ascertaining quantum. ${ }^{39}$ Congress might authorize a hearing process in which a range of standards could be drawn on in formulating orders for different situations. But for the moment, the standard for measuring the quantum of reserved water remains unresolved. ${ }^{40}$

\section{B. Purpose and Intent: The Federal Strategy}

The measure of Indian water rights is closely linked to the federal purposes underlying the reservation of these rights. If the interest of the federal government is in fostering Indian agriculture, a very different entitlement will be involved than if the federal purpose is one of economic rehabilitation across a broad front. It remains unclear whether the quantum of water may vary with the definition of rehabilitation or changes in federal strategy. Although no answer has received judicial approval, a flexible approach is more consistent with national history. Reservations were established in part to aid the Indian community prepare for life in a white dominated society. The purpose of reservations might, then, vary somewhat from decade to decade. ${ }^{41}$ If, under Winters, one must look to the original purpose to determine an intention to reserve waters, it may be argued that the federal government, in furtherance of its general rehabilitative purpose, must be prepared to shift water to municipal and industrial uses when such action is itself in the interests of the reservation. The Winters reserved rights would, then,

theory may well mean the difference between survival and dehydrated extinction for competing non-Indian irrigators." Sondheim \& Alexander, supra at 24.

36. This was the standard applied in United States v. Walker River Irrigation Dist., 104 F.2d 334 .

37. A flexible order was provided in Conrad Investment Co. v. United States, 161 F. 829 (9th Cir. 1908).

38. It is, however, important to distinguish finality from quantum. A court can take an approach which is liberal to the reservation in terms of the quantum of water available in the future, but which resolves the question finally. On the other hand, a court can award only modest in praesenti rights, leaving open the decree for modification on a showing of need by the reservation.

39. Cf. Burt, Miranda and Title II: A Morganatic Marriage, 1969 Supreme Court Rev. 81, discussing Katzenbach v. Morgan, 384 U.S. 641 (1966); Pyramid Lake Paiute Tribe v. Morton, 354 F. Supp. 252 (D.D.C. 1973).

40. Not only the standard is at issue: there is also the question of time. Is the Winters right completely open-ended? Is it open-ended only until the time of quantification, whenever that occurs? Or does the time involved vary with each case?

41. Cf. United States v. Clapox, 35 F. 575, 577 (9th Cir. 1888). 
constitute a class of uses any one of which could be important for the "improvement" of the Indians residing on the reservation. ${ }^{42}$

\section{Alienation and Off-Reservation Use of Reserved Water Rights}

Complicating the issue of the uses to which Indians may apply their water rights is the question of alienating these rights. No legislation specifically prohibits the alienation of Indian water rights. The Supreme Court, in United States \%. Powers ${ }^{43}$ upheld the action of a lower court which had determined that non-Indian successors in interest to Indian allottees also hold the water rights implicitly conveyed to those allottees when the latter obtained titles to parcels of reservation land ceded by the tribe. However, the Supreme Court declined to define the precise nature or extent of the successors' rights in the water. A tribe may be able to lease or sell confirmed rights but it may not thereby be able to add to the quantity of water to which it is entitled. ${ }^{44}$

A similar question arises as to the location of use of reserved water rights. It is unlikely that under Winters a tribe could claim that it was going into the wholesale water leasing business as part of the "future needs of the reservation" and that all downstream users would thereafter have to lease water from the tribe. But even where a limitation has been set on quantum, it is unclear whether the exploitation of reservation water must be limited to the reservation itself. On the one hand, it may be argued that since tribes can use the proceeds from land leases for off-reservation investment so, too, it should be able to apply its water rights to various locations. On the other hand, if the purpose of the right is to make reservation lands livable, offreservation uses could be held impermissible. Picking at the bones of Winters provides little guidance. Uncertainty about alienability and location of use renders it difficult for a tribe to assess the validity of a particular transaction and contributes to the hazards of the bargaining process.

\section{Duration of Reservation Immunity}

To say that there are reserved rights does not say how long those rights are reserved. One threat to these rights is the possibility that the Congress

\footnotetext{
42. If the shift in federal purpose resulted in an increased quantum of water for Indian use non-Indian users would, of course, raise the usual objection of uncertainty. Use does not, however, need to be linked solely to irrigable purposes. As in the Pyramid lake situation, one might look to the original purpose of maintaining the lake as a fishery to determine the quantum reserved, and then maintain that quantum even if the lake is later used for tourism and recreation.

43. 305 U.S. 527 (1939).

44. Tweedy v. Texas Co., 286 F. Supp. 383, 385 (D. Mont. 1968) explicitly suggests that possibility: "It seems clear . . . that need and use are prerequisite to any water rights on Indian reservations." The decision, however, has been severely criticized as being inconsistent with the established view of Winters doctrine rights as reserved rights distinct from appropriative rights. See Leaphart, supra note 1.
} 
will terminate the reservation..$^{45}$ It could be argued that the purpose of the reservation was to give to the tribe a limited period of immunity from the rigors of the appropriation doctrine and state regulation. To be sure, under an approach which viewed such immunity as limited in time, it would be difficult for courts, unaided by Congress, to determine what the limit should be. ${ }^{46}$ Yet we know that the trust of land is terminable and that Congress can ordinarily determine that an Indian resource can be subjected to state laws without effectuating a taking. ${ }^{47}$ Congress could state that, as of a particular time, the community's entitlement to water would be subject to state regulation. ${ }^{48}$ To avoid destruction of vested rights, the Congress would be obliged to state that existing, beneficially used rights, as quantified under Winters and Arizona, would maintain the vitality and priority held prior to the legislation and would be protected against taking by the fifth amendment. ${ }^{49}$

This approach is, however, wholly at war with the widely accepted view. It is more generally regarded that the Winters reservation was not only an immunity from state regulation, but the reservation of a fixed right by a collective group to a variable amount of water, the terms of the right being largely governed by the settlement. ${ }^{50}$ Without clarification, however, the threat of subjecting reservations to state water laws will continue to affect the bargaining posture and planning capabilities of the Indian tribes.

\section{Technology}

Another uncertainty is whether changed technology is to be taken into account in defining the scope of the reserved right. When the Navajo Reservation was created, most Colorado River water was inaccessible because its

45. See the infamous H.R. Con. Res. 108, 83d Cong., 1st Sess. (1953).

46. See United States v. Cisna, 25 F. Cas. 422 (No. 14,795) (C.C. Ohio 1835); cf. United States v. Bailey, 24 F. Cas. 937 (No. 14,795) (C.C. Tenn. 1834).

47. See Johnson v. McIntosh, 21 U.S. (.8 Wheat.) 542 (1823); cf. Goldberg, Public Law 280: The Limits of State Jurisdiction Over Reservation Indians, 22 U.C.L.A.L. REv. 535 (1975). Congressional action subjecting a tribe to state and local jurisdiction must, however, be interpreted strictly. Menominee Tribe v. United States, 391 U.S. 404 (1968); Santa Rosa Band of Indians v. King's County, Civil No. 74-1565 (9th Cir., filed Nov. 3, 1975). Since the Supreme Court has not determined that the federal government has authorized the states to impose zoning and other land use restrictions on Indian land there is no holding determining that a grant of regulatory jurisdiction to the state constitutes a compensable taking. $C f$. Snohomish County v. Seattle Disposal Co., 389 U.S. 1016 (1967) (Douglas, J. dissenting from denial of certiorari).

48. Compare deferment of state taxation of lands conveyed to Alaska natives under the Alaska Native Claims Settlement Act, 43 U.S.C.A. $§ 1620$ (d) (1971).

49. Compare the concept of "recognized" and "unrecognized" rights to land in determining fifth amendment compensability. Northwestern Bands of Shoshone Indians v. United States, 324 U.S. 335, 355 (1945) (Jackson, J. concurring). See also 28 U.S.C. § 1360(b) (1970), which prohibits state courts assuming jurisdiction under 28 U.S.C. $\$ 1360$ (a) (1970) from alienating, encumbering or taxing Indian property (specifically including water rights) that is held in trust, and forbids their regulating such property in a manner inconsistent with federal treaties.

50. See Veeder, Indian Prior and Paramount Rights versus State Rights, 51 N.D.L. REv. 107 (1974). 
flow was deep in canyons. Enormous investment and the construction of Glen Canyon Dam now make the water more readily available.

Limiting technology seems a less principled way of defining the water right than looking to the purpose of the reservation. If the purpose of immunity from the doctrine of prior appropriation were to allow technology to catch up with the needs of reservation lands, a principle forcing inefficient uses of water resources would be intolerable. On the other hand, technology undoubtedly has a role to play in determining what is "practicably irrigable." It might be established that a tribe can employ whatever technology it chooses to extract and deliver water, but the quantum will be limited to what seemed practicably irrigable with reference to a technology at a fixed date. But what is practicable is a function both of technology and cost. It is hard to read into the Winters right a limit on the amount that the federal government can expend to assist in diversion projects and in the construction of works for beneficial uses. Similarly, the United States must be free to develop and apply its water technology to Indian reservations without judicial limitation on congressional appropriation.

A somewhat different issue is presented where private non-Indian users on the reservation apply vast resources and technology to the exploitation of the Indian right. One might argue that the Winters right was limited by the capacity of the tribe and the willingness of the federal government to provide the capital to effectuate the right. Circumscribing exploitation of the right by limiting the class of institutions that could participate would have been an effective way of placing a ceiling on the right. Such a rule would have a political safety valve for non-Indian competitors for water since they would have a significant, indeed dominant, say in the legislative process. By opening exploitation to private interests, control is lost over the extent to which "future needs" can burgeon.

A remote analogy can be found in state regulation of off-reservation hunting and fishing based on the mechanism used by the Indians in the exercise of their right. Many states have, for example, attempted to prohibit Indians from using set nets or gill nets at off-reservation sites. The Puyallup case dealt with the power of the state, in its pursuit of conservationist goals, to limit the use of set nets along the Columbia River. ${ }^{51}$ Courts were asked to interpret the basic right of the Indians by determining whether a sharp advance in the means of exploiting the right could be prohibited or regulated. If subsistence was the basis of the right, then, it was thought, the state could ensure that techniques incompatible with subsistence fishing could be prohibited. On the other hand, in the most recent cases, ${ }^{52}$ the courts seem to

51. Puyallup Tribe v. Department of Game, 391 U.S. 392 (1968); Department of Game v. Puyallup Tribe, 414 U.S. 44 (1973).

52. United States v. Washington, 384 F. Supp. 312 (W.D. Wash. 1974), aff'd, 520 F.2d 676 
suggest that what was reserved was a quantum of fish-a fishery-and there is a positive duty on the part of the state to assure that the fishery is available. Technology is not so important as the quantum expectation.

\section{Principles in Context}

All of this is part and parcel of administering the "meaning" of Winters in the most technical sense. But there is a flaw in any doctrinal analysis that relies solely on an elaboration of legal principles. A principle has the potential to be effective only when asserted; and even then the assertion of a principle may be in vain. In the development of Indian resources the usefulness of a legal principle may be deeply affected by the availability of an appropriate forum, ${ }^{53}$ adequate counsel, ${ }^{54}$ and sufficient funds to sustain complex litigation. Sometimes a legal right may be used in a process of bargaining rather than principle vindication. Often, an Indian resource right is used by the tribal government, or the federal government as its representative, to obtain another sought-after goal for the tribe: In the treaty-making period, disputed claims to land were traded for seeming peace and certainty, while in the later nineteenth century so-called surplus lands were traded for additional money and individual allocations of land. ${ }^{55}$ Today, a tribe may determine that it wishes a particular kind of economic or social development and that it is willing to exchange its uncertain water rights to further that particular goal.

Indeed, because tribes have traditionally not had the capital to exploit a resource by themselves, the exchange value of the resource has been a critical issue. The valuation of a resource for the purposes of exchange usually involves the allocation of risks among the parties to the exchange. There is the risk that the existence or costs of extracting a resource will prove too great, or that future government regulation may alter the value of the resource. In the case of the Indians' valuation of their water rights, there is the additional uncertainty of not knowing whether the outer logical boundaries of the Winters doctrine will really be possible of achievement. Winters is a cloud on the development of water in the arid regions of the Southwest. How much the states are willing to expend to see the cloud dispelled depends on how large and black that cloud is perceived to be.

Uncertainty may also exist in the social and political implications of asserting a resource right. Of considerable importance is the actual and per-

(9th Cir. 1975), cert. denied, 96 S. Ct. 877 (1976); Sohappy v. Smith, 302 F. Supp. 899 (D. Ore. 1969); Comment, State Power and the Indian Treaty Right to Fish, 59 CAL. L. REv. 485 (1971).

53. See note 3 supra.

54. See Price, Lawyers on the Reservation: Some Implications for the Legal Profession, 1969 LAw \& Social Order 161.

55. See M. PrICE, supra note 7, at 441 . 
ceived viability of the tribal government that is asserting the Winters right. Because the national policy for decades was premised on the ultimate disappearance of tribal sovereignties and the assimilation of Indian people into the mainstream population, non-Indian competitors for water rights may have assumed that a policy of waiting was compatible with ultimate disappearance of the Winters cloud. ${ }^{56}$ Indeed, the Indian's own scale of relative values may be influenced to a large extent by what the federal government has suggested is of greatest value to the development of the Indian society.

The Navajo experience in the 1960 s provides an opportunity to examine the unfolding of the Winters right in this context. Throughout the decade, the pressure for power development and greater supplies of water for southwestern cities brought pressure for a resolution or definition of Navajo water rights. Extraordinary public expenditures were necessary before regional goals could be realized. Such expenditures were, however, inconsistent with the risk of uncertain sources of water. In particular, there were two occasions when the Navajo Tribe was obliged to determine whether it was interested in bargaining its Winters claim for other values. In 1962, Congress confirmed a tribal determination providing for federal financing of a massive irrigation project on the eastern portion of the reservation in exchange for a surrender of the Navajo priority to waters needed for the San Juan-Chama project. And again, in 1968, the tribe resolved to forebear from using Colorado River water on the western portion of the reservation in exchange for some monetary consideration and the promise of beneficial economic development, actions which made possible the construction of the Navajo Generating Station. In analyzing these two decisions, an effort will be made to appraise the efficacy of the Winters right by describing some aspects of the institutional context in which it was deployed.

\section{A. The Navajo Generating Station}

As indicated above, the Upper Colorado River Basin Compact of 1948 apportioned the consumptive use of 7.5 million acre-feet among Colorado, New Mexico, Utah, Wyoming, and Arizona. While the compact specifically declared that nothing within it affected the obligations of the United States to the Indian tribes, ${ }^{57}$ it was generally assumed that the 50,000 acre-feet ${ }^{58}$ allocated to Arizona would suffice to meet any Navajo claim. Although there was no question that the states, agreeing among themselves, could determine that Navajo uses in Upper Basin Arizona would be charged against Arizona's entitlement, it was far less certain that the states, even with congressional confirmation, could limit the Navajo entitlement itself.

56. See, for example, the discussion of the "New Policy" of 1917 in L. Kelly, The Navajo Indians and Federal Indian Policy 1900-1935, at 132 (1968).

57. Colorado River Compact, art. VII, 70 ConG. REC. 324, 325 (1928).

58. Id. art. III(a), at 325 . 
Vagueness on this issue had been imperative in 1948. There was no appetite to include the Navajos or other Upper Basin Indian tribes in the deliberations leading to the 1948 Compact. Nor was there a desire to confront and define the outer limits of the Navajo water right. Winters could be discounted as an obscure and perhaps obsolete piece of jurisprudence. Federal Indian policy in the post-war period was aimed at the reduction of "special rights" for Indian tribes. ${ }^{59}$ The seeds of termination had already been planted. It would not have been absurd for the Upper Basin states to assume that the issue of potential Indian water claims would take care of itself.

By the mid-1960s, the virtues of postponement were no longer apparent. In 1964, the Salt River Project (SRP) applied for a permit to appropriate waters of the State of Arizona for the purpose of constructing a coal-fired electric generating station on the Navajo Reservation. ${ }^{60}$ And in March 1965, the SRP applied for Lake Powell water from the Department of the Interior for the same purpose. ${ }^{61}$ Most significantly, a consortium of electric utilities had been organized under the name "WEST," short for Western Energy Supply and Transmission. WEST would allow the several electric utilities to take advantage of economies of scale to provide the generation, transmission, and supply of electricity to their customers. ${ }^{62}$

To obtain the needed water, plant sites, and transmission rights of way, WEST would have to apply to the Department of the Interior. Inevitably, the terms upon which WEST was licensed to use these resources would be the subject of negotiation. Discussions between the Department of the Interior and WEST began in early 1965 on studies of power supply and related problems. With President Johnson's hope that a formula for joint public and private resource development in the Colorado Basin could be found, tentative agreement on a cooperative approach in the energy arena was initiated in early June 1965. Basically the agreement under discussion called for a gigantic pooling of the power resources of several large private and municipal power producers with those controlled by the Bureau of Reclamation. The private and municipal participants hoped to utilize existing giant steam-generating plants and proposed to produce firm, continuous power and to rely upon hydroelectric plants of the Bureau of Reclamation, present and future, to provide power during hours of peak consumption. Studies

59. See Watkins, Termination of Federal Supervision: The Removal of Restrictions Over Indian Property and Person, 311 AnNals 47 (1957).

60. State of Arizona Application No. A-4753 (Dec. 19, 1964) (on file with the Arizona State Water Commission, Phoenix).

61. Letter from R.J. McMullin to Stewart L. Udall, March 22, 1965.

62. The participating members of WEST in the NGS were the Salt River Project (project manager), Los Angeles Department of Water and Power, Arizona Public Service Co., Nevada Power Co., Tucson Gas \& Electric Co., and the U.S. Bureau of Reclamation. Indeed, as project manager, the prior actions of Salt River, described supra, were on behalf of the coalition. 
on this as well as on cost and efficiency gains through future construction and integration of transmission lines were also initiated. Secretary Udall argued that without cooperative planning and coordination between the federal government and the public and private sectors of the utility industry, the probable result would be a less efficient and reliable power system.

By the spring of 1966, negotiations were under way between Secretary Udall and WEST to integrate WEST thermal power with the hydroelectric peaking power to be produced from the Hualapai and Marble Canyon dams. And by August 1966, a "preliminary letter agreement" had been entered into by the Secretary of the Interior and WEST laying down general guidelines for an arrangement that would be "mutual[ly] advantageous." 63

By late 1966, interest in a Page power plant had considerably increased. ${ }^{64}$ It had become clear that there would be no dams in the Grand Canyon to furnish pumping power for the Central Arizona Project. An alternative source of energy and a plan allowing for government participation in a private power plant, through prepayment of capital, was devised. Within a few months negotiations for a water service contract between the Salt River Project and the Bureau of Reclamation commenced. ${ }^{65}$

To build support and dampen potential conflict the SRP held a series of meetings with the Arizona Interstate Streams Commission, the Central Arizona Project Association, and the Arizona Power Authority. ${ }^{66}$ Endorsement was sought for a plan to tap Arizona's share of the Upper Basin allocation for the cooling water needed at the plant.

On February 1, 1967, Secretary Udall unveiled the administration's new proposal for the Central Arizona Project (CAP). ${ }^{67}$ This new arrangement

63. M. Udall, Language for Committee Report on H.R. 4671, Aug. 9, 1966 (unpublished manuscript on file with author). The Department of Interior informed the power companies involved in the Four Corners, Mohave, and Page power complexes that water service contracts, rights-of-way, permits and approvals could not be made unless they agreed upon arrangements to coordinate their fossil fuel generating resource with Department of Interior hydroelectric resources. Hearings on Problems of Electrical Power Production in the Southwest Before the Senate Comm. on the Interior and Insular Affairs, 92d Cong., 1st Sess. 1742 (1971). See also the exchange of letters between Stewart L. Udall and Jack Horton, President, Southern California Edison Company, in id. at 332-51.

64. Hearings on Problems of Electrical Power Production in the Southwest, supra note 63, at 1741.

65. Id. at 1741-42.

66. The meetings were to completely brief these organizations on the Page plant, the use of a part of the 50,000 acre-feet allocated to Arizona, and the benefits of the Page plant to Arizona citizens. In the case of the Interstate Streams Commission and the Central Arizona Project Association, the meetings were also devoted to requesting an endorsement of each for the consumptive use of part of Arizona's Upper Basin Allocation in the proposed Page plant.

Id. at 1748 .

67. U.S. Dep't of Interior, Summary Report: Central Arizona Project with federal Pre-Payment Power Arrangement (1967). The CAP was revised in two significant areas. First, the CAP was to be an independent development without financial assistance from the Lower Colorado Basin Development Fund as proposed in legislation reported on during the Eighty- 
provided that the federal government prepay a portion of the capital cost of a large thermal power plant and related transmission system which would be constructed near Page, Arizona, adjacent to Lake Powell, by a consortium of electric utility companies. Coal for the plant would be obtained from the Black Mesa fields on the Navajo Reservation.

By fall of 1968, Congress had passed a statute permitting federal prepurchase of power from a thermal generating station. ${ }^{68}$ It was clear from previous actions of WEST and its project manager, SRP, that the plant would be located at Page, utilizing water of the Upper Basin and coal from Black Mesa. All that was unsettled was the status of the water. Congress had commanded that the water used be charged against the 50,000 acre-foot Arizona entitlement. ${ }^{69}$ But the unresolved question, which could result in disunity, was just how much water was available from the 50,000 acre-feet of Arizona's allocation for use by the power plant.

The total amount of water to be contracted could not be determined until definitive studies of present water usage in Arizona's Upper Basin were instituted and completed. An operating assumption, to avoid the possibility of conflict, was that unless all parties interested in the 50,000 acre-feet reached agreement, ${ }^{70}$

there could be no multimillion dollar project using this water. The touchstone of the effort to acquire the water supply was that negotiations with all entities having the basis for valid claim to Arizona's Upper Basin Allocation would take place and that there be no effort to prosecute to final court conclusion the legal claim of any one or more of them.

If the Navajos claimed water for their reservation in addition to the total water already in use and earmarked for the project, or if they claimed under the Winters doctrine that they were entitled to more than 50,000 acre-feet, the calculations of Upper Basin users would be sorely jeopardized. The Navajos had never agreed to a 50,000 acre limit on their water use for that portion of the reservation lying in Arizona and draining from the Upper Basin. The consent of the tribe to the construction of the Page plant (to be called the Navajo Generating Station, or NGS) was viewed as essential if the tribe's water rights were to be limited to 50,000 acre-feet and the needs of the NGS were to be charged against the reservation's thus limited settlement.

ninth Congress. Secondly, Marble Canyon was to be placed in an enlarged Grand Canyon National Park and final decision on the Hualapai Dam reserved for future congressional action. This meant there would be no dams on the Colorado River to provide power for the CAP. Instead, the Secretary of Interior would be authorized to make arrangements with non-federal interests to acquire the right to a portion of the capacity of the output of a large thermal power plant as necessary to serve project purposes.

68. Act of Sept. 30,1968 , Pub. L. No. $90-537, \S 303,82$ Stat. 889 , as amended, 43 U.S.C. $§ 1523$ (1970).

69. Id.

70. Hearings on Problems of Electrical Power Production in the Southwest, supra note 63, at 1740 (emphasis added). 
An agreement was eventually reached. Although it is somewhat ambiguous, and although there were conflicting interpretations after the fact, there were clearly those who believed that the final resolution consituted an effective recognition by the tribe that their entitlement to Upper Basin Colorado water in Arizona remained at 50,000 acre-feet. The resolution reads as follows. ${ }^{71}$

1. In consideration of the Secretary of the Interior executing a contract between the United States and Salt River Project Agricultural Improvement and Power District, operator of the coal-fuel power plant, committing the use of approximately 34,100 acre-feet of water per year for the power plant to be located on the Navajo Reservation near Page, Arizona, the Navajo Tribe of Indians agrees that they will not make demands upon the 50,000 acre-feet of water per year allocated to the State of Arizona, pursuant to the Colorado River Basin Compact, in excess of 50,000 acre-feet of water per year, of which 34,100 acre-feet of water per year shall be used by the coal fuel power plant to be located on the Navajo Reservation near Page, Arizona.

Explicit discussion of the Winters doctrine did not play a major part in the negotiations concerning the Navajo Generating Station and the ensuing resolution. Negotiations differ from litigation in the way the doctrine is used. In negotiations, the focus is on the quantity and form of consideration rather than on the fine points of legal argument. Yet legal rights are only barely beneath the surface, setting a background for the bargaining power of the parties. The written material prepared during the critical period, including the minutes of Tribal Council meetings, does not indicate any elaborate discussion of the potential claims that the Navajo Tribe might have had under the Winters doctrine in the Upper Basin. No effective challenge to the 50,000 acre-foot limitation was argued by the tribe. Instead, the emphasis was on the form of compensation that would be paid for a waiver of tribal claims to the water needed by the Salt River Project to operate the Navajo Generating Station.

The weak role that the Winters doctrine played in the deliberations can be explained in several ways. One possible explanation lies in the relation-

71. Navajo Tribal Council, Resolution No. CD-108-68, December 11, 1968 (Navajo Tribal Council minutes and resolutions are on file with the Office of the Clerk, Navajo Tribal Council, Window Rock, Arizona). The other significant parts of CD-108-68 for the Winters doctrine were:

RESOLVED: 3. It shall be understood that the Navajo Tribe's promise to limit its claim to 50,000 acre-feet of water per year shall only be for the term of the lifetime of the proposed power plant, or for 50 years, whichever shall occur first. . .

WHEREAS: 6. Because the 34,100 acre feet of water per year must come from the 50,000 acre-feet of water allocated to the State of Arizona by the terms of the Upper Colorado River Basin Compact, the Salt River Project Agricultural Improvement and Power District must be assured that the Navajo Tribe will not assert, for the lifetime of the proposed coal-fuel power plant, or for the next 50 years, or whichever occurs Id. first, claims for water in excess of 50,000 acre-feet per year. . . . 
ship between the information gathered by the tribe and the ultimate tribal decision. Acting consistently with one's self interest is said to be "a function of choice and information." ${ }^{72}$ It is thus assumed that the possibility of protecting one's interests declines where information and choice are unavailable or restricted. During the policy process, decision makers eventually develop a particular impression of the issue involved. Information is compiled and utilized on the basis of that impression. Likewise, their perception of the issue naturally makes them more receptive to what they want to hear. As a result, they are more favorably inclined towards data which support or justify actions they desire. All other information is extraneous and perhaps even induces conflict.

The overriding issue for the Navajo Tribe was the need for jobs and increased revenues. The tribal leaders perceived that a strong bargaining stance could jeopardize those economic goals, and the negotiations show that they were particularly receptive to information which was consistent with those goals. To the Indians, the main issue was not the threat to their water rights. Information in this regard was minimal and, when presented, it seemed to make no impression. Information of this type was overshadowed by the promise of near-term economic benefits from the NGS. Conflict could have resulted if information concerning Winters had received greater emphasis.

Of perhaps even greater importance were the sources from which the tribe drew its information. The Navajo Tribal Council gained its information primarily from the SRP, the Bureau of Reclamation, and the Upper Colorado River Commission-the entities that were negotiating with the tribe. Data on current water usage, irrigable acreage, future water use alternatives, and benefits to the tribe were primarily prepared by non-Navajo interests. ${ }^{73}$ In-

72. H. Ingram, The Politics of Water Allocation 4, February 28, 1974 (unpublished paper presented before the American Association for the Advancement of Science, Committee on Arid Land, San Francisco).

73. By mid-1968 when the non-Navajo parties had already resolved that NGS use of water should be charged against the Navajos and that the Navajo claim should be limited to 50,000 acre-feet, it became imperative to assess the existing uses of water in the Upper Basin portion of the reservation. Accordingly, representatives of the Bureau of Reclamation, the Upper Colorado River Commission (UCRC), and the Resources Department of the Navajo Tribe undertook a water usage survey in the spring of 1968.

The survey estimated that there were 17,912 acre-feet of water in present use. However, the Arizona Interstate Streams Commission estimated that there were only 8,167 acre-feet in use. Unity, and the pressure of time, demanded that these differing estimates be immediately reconciled. A meeting was held on October 3, 1968 for just this purpose between the staffs of the Upper Colorado River Commission and the Arizona Interstate Streams Commission. It is not clear just how these differing estimates were reconciled but it should be noted that the average of the two estimates, about 18,040 acre-feet, was within ten acre-feet of the estimate of Navajo water usage in Arizona's part of the Upper Basin presented to the Navajos during the December negotiations. At that point, little effort was made to assess more carefully the scope of existing Navajo use. Despite the fact that the Solicitor had already ruled that Winters doctrine water could be put to nonagricultural use, there apparently was no effort to determine the Upper Basin potential of the Navajos for such a utilization of their water. The compromise 
deed, the original resolution presented to the tribe was prepared by the Department of the Interior and the Bureau of Indian Affairs (BIA).

Potential, if not real, conflicts of interest inhered in this information gathering process. The BIA is but one agency of the Interior Department whose departmental policies often overwhelm competing or conflicting Indian interests. ${ }^{74}$ The major BIA official at Window Rock was reported to have said that the only thing he could have done was resign if he did not follow the orders of the Secretary of the Interior to obtain a waiver of Navajo water rights. ${ }^{75}$ One example involves the key perception of mutual benefits. The impression left by non-Navajo interests was that the coal mine and the power plant were intimately related. It is difficult to ascertain the exact amount of benefits accruing to the Navajo Tribe as a result of the negotiations. The most impressive total presented was a $\$ 3,045,000$ annual contribution to the Navajo economy. ${ }^{76}$ This certainly is large relative to the gross national product of the reservation, but a breakdown of that total is instructive: $\$ 1.6$ million came from coal royalties, $\$ 1.4$ million from wages, and only $\$ 45,000$ from the plant site lease itself, about 1.5 per cent of the total benefits. From the $\$ 1.4$ million in wages, only $\$ 200,000$ would come from employment at Page, making a total of $\$ 245,000$ per year. In this way, benefits from the mine were always included when arguing benefits from the Page project. It was true that the tribe could not benefit from the power plant without coal to burn, but coal royalties ultimately may not have been dependent on the existence of the Navajo Generating Station, although an opposite impression was left with the Tribal Council. ${ }^{77}$

Ideas of sovereignty and concepts of the trust responsibility are vital to understanding and evaluating the bargaining roles with respect to such major resource allocation decisions as the possible waiver of rights in the upper Colorado River Basin. There is the question whether the Bureau of Indian Affairs had the technical capacity to act in any trust role with respect to major resource decisions on the Navajo Reservation. A more modern percep-

struck by the Interstate Stream Commission and the Upper Colorado River Commission became the law of the case.

74. Chambers, Discharge of the Federal Trust Responsibility to Enforce Legal Claims of Indian Tribes: Case Studies of Bureaucratic Conflict of Interest, in STAFF of Senate Comm. on the Judiciary, 91 st Cong., 2d Sess., Study of Administrative Conflicts of Interest in the Protection of Indian Natural Resources (Comm. Print 1970).

75. Gallup Independent, May 31, 1969, at 1 .

76. Navajo Tribal Council 344, December 9, 1968.

77. Graham Holmes, Superintendent at the Navajo Agency, said, "There's more coal here than they need at Bullhead City. So, if you're going to sell all this coal you've got to have both of these plans." Id . at 353. He also said, $i d$. at 349, that "we don't find anything else you can do with the coal." A council member agreed, "we want the power plant located on the Navajo Reservation so our coal could be used." Id. at 354. It was also estimated that the wages paid, because of the multiplier effect, would mean an extra $\$ 8$ to $\$ 10$ million a year boost to the economy. No mention was made that this multiplier effect might be siphoned to non-Navajos in the border towns. 
tion of the trust responsibility may be to have the federal government remain in the background, letting the reservation make its own decision with respect to the appropriate bargain. ${ }^{78}$ Harmonizing the trust responsibility with rising expectations of sovereignty is difficult. But in the deliberations surrounding the resolution of Navajo water rights, the Department of the Interior played conflicting roles with respect to Colorado River water, roles that made it difficult objectively to advise the Navajo Tribe.

In terms of technical assistance to the tribe, little, if any, came from the Bureau of Indian Affairs itself. ${ }^{79}$ As indicated, much of the data had been prepared and analyzed by the Bureau of Reclamation, an agency in the department with interests clearly adverse to those of the Navajo Tribe. The Bureau's consultations came primarily through the assistance of the solicitor's office and the participation of the superintendent's office of the BIA's Navajo Agency. Both sources of help were bound to propound the department's position. The BIA was not well equipped to evaluate alternatives. It has traditionally been viewed within the department as a weak and uninfluential branch. With few exceptions, economists, hydrologists, and other technicians would be found in the Bureau of Reclamation rather than the Bureau of Indian Affairs. Certainly, on this occasion, the BIA did not independently evaluate the needs of the tribe and make recommendations to it.

The conflict of interest between the Secretary of the Interior as trustee for the Navajo Tribe and as a public official responsible to a national and departmental constituency was apparent. First, the Department of Interior would obtain a portion of the capacity of the proposed plant as a result of the recent passage of the Colorado River Basin Project. ${ }^{80}$ Indeed, the WEST proposal had its long range positive aspects for the future of Bureau of Reclamation projects in the region. For example, WEST was essentially a proposal to produce base load energy which could enhance the value of hydroelectric peaking power under circumstances of high demand and low supply. The existence of such large amounts of low cost base load energy could further enhance other projects proposed by the Bureau of Reclamation. The Bureau of Reclamation had close and beneficial working relationships with the consortium of power companies. The federal government was prepurchasing a sizable amount of power, contributing a sizable amount of the capital costs, and would undoubtedly help to facilitate negotiations for coal, water, and permission from the appropriate entities-the State of Arizona

78. See Chambers \& Price, Regulating Sovereignty: Secretarial Discretion and the Leasing of Indian Lands, 26 Stan. L. Rev. 1061 (1974).

79. Navajo Tribal Council 349, 353, 382, December 9-10, 1968. For example, the Bureau of Reclamation made the study of alternative uses for the water and concluded that the Page plant was the best.

80. Act of Sept. 30, 1968, Pub. L. No. 90-537, 82 Stat. 885. 
and the Navajo Tribal Council. ${ }^{81}$

There is current debate over the proper role of the federal government in decisions involving the allocation of reservation resources. ${ }^{82}$ The more traditional view is that the Secretary should have a veto power to determine that the decision made meets fair market value requirements and is consonant with the long term best interests of the tribe. The Secretary, under this view, cannot command that an action be taken over the opposition of the tribal government, and the views of the tribe should be given great weight before the Secretary forbids it from taking a particular action. A competing view is that the duty of the trustee is to insure that the tribal government is well informed and the consequences of alternate forms of action are well known. According to this view, the trustee's duty is to provide data and the basis for analysis but not to overrule the decision of the tribe itself.

Clearly, the federal government, in particular the Secretary of the Interior, played neither of these roles adequately in the NGS context. The deep and certain conflict of interest prevented the Secretary from performing the traditional trust role. The Bureau of Reclamation had too great a stake in the outcome. Nor did the Secretary perform the second role adequately, largely because of the lack of expertise and forcefulness of the Bureau of Indian Affairs. Here the United States was purporting to act as the trustee and the Navajo Tribe was relying on that representation. But nothing in the period leading up to the December 1968 resolution suggested that the role could be performed adequately by the department.

Another important factor in the negotiations involving the resolution of Winters rights was the relative economic strength of the parties and the consequent need to have an immediate settlement. In 1968, the Navajo Tribe was said to be severely underdeveloped: living, health, and educational standards were far below the national norm. ${ }^{83}$ Unemployment was extraordinarily high. And oil royalties, upon which the tribe depended for many of its own services, were seriously depleted. As a political matter within the tribe, jobs were a matter of first priority. The value of immediate additional employment on the reservation had a political and social significance greater than more remote, but possibly more valuable, alternative uses of Colorado River water. The power plant construction would, furthermore, spur eco-

81. Not to be overlooked were the close ties, personal and/or business, that existed between certain members of WEST, members of the Department of the Interior and the CAP lobby. Two members of WEST that were to build the Page plant were the Salt River Project (SRP) and the Arizona Public Service Company (APS). Both these utilities were members of and contributed financial and personal support to the lobbying efforts of the Central Arizona Project Association. Arizona periodically sent a "task force" of persons with good Department of the Interior connections to testify at congressional hearings on the CAP.

82. Chambers \& Price, supra note 78.

83. Aberle, A Plan for Navajo Economic Development, in 1 Jornt Economic Comm., 91st Cong., 2d Sess., Toward Economic Development for Native American Communities 223 (1969). 
nomic development in one of the most depressed areas of an already economically underdeveloped reservation. ${ }^{84}$

It would be difficult for a financially pressed tribal government, representing a constituency in need of economic benefits, to await the full blossom of Winters rights. The reserved waters doctrine at the base of Winters assumes that there will be a slow maturation of the tribe's purposes. At the heart of Winters is the idea that the settler community should not be able to withdraw and commit water that might be needed by the tribe at a future time as it gains the machinery to exploit its resources. But the tribe itself may see the need to cut short Winters delaying power. More limited economic development in the present has an appeal that postponed development may lack. The tribe may well reason that the kind of federal financing necessary for massive tribal growth and use of its resources will not be forthcoming, especially if the exploitation of resources by the tribe conflicts with the needs of the dominant settler culture. ${ }^{85}$

It is possible to argue that the Navajo Tribe, having accepted the importance of a present settlement of Winters rights for economic development, became a true member of a coalition of economic interests, albeit one that

84. At least 150 Navajos would be employed in site development and plant construction, followed by up to 20 Navajos employed in plant operation with an anual payroll of $\$ 200,000$; some 110 to 130 Navajos employed at coal mining with an annual payroll of $\$ 400,000$; another 30-40 Navajos employed in supporting industries with an annual payroll of $\$ 300,000$. The 34,100 acre-feet needed for the plant was portrayed as a "trade-off" for revenue, development, and jobs. Also it was argued that the power plant was the only way the water was likely to be used within the immediate future, if ever. The General Manager of SRP told the Tribal Council, "we believe that by combining water with Black Mesa coal we can produce an economic benefit which exceeds any other known use of those resources. . . . We need electricity which your coal and water will produce to your benefit and ours." Navajo Tribal Council 366, December $10,1968$.

One of the tribal attorneys was even more forceful:

The question always posed to the Legal Department, is this a good deal when anything is brought up. Based upon the information that has been given us from the Resources Department of the Navajo Tribe, and looking at the legal problems to the best of our ability, I think that this is a good deal. The question that you might ask yourself is, if you don't agree with this deal, what are you going to do with the water? Can you think of anything that can be done with it that will bring $\$ 300,000,000.00$ to the western Reservation and provide many, many jobs for the Navajos? Certainly, not agricultural use. And I don't know of any other company that is interested in coming to the western Reservation now or the next twenty or thirty years. The people of the western Reservation need jobs and they need the money. Id. at 339 .

85. Because of the value of jobs, all the possible consequences of a decision to build a power plant were not adequately identified or taken into account. The participants focused only on the direct and immediate effects of the proposed power plant and ignored the possible longrun consequences. Questions of whether the Reservation should be developed by capital intensive industry rather than by labor intensive industry and for what purposes were ignored. What would happen when the life of the plant was over and the coal exhausted? A situation of arrested development and stagnation was not recognized as a possibility. What could be the adverse social effects of the plant on the surrounding population? What effect would it have on tourism? The effect of the plant on the environment was not even mentioned. 
perhaps did not exact sufficient tribute as a condition of entry. The tribe, like the other participants, would gain by becoming part of an alliance that could produce federal benefits available to all. A complex series of interrelated events would lead to enhanced economic development on the western reservation. Legislation and the waiver of possible water use rights were essential. To accomplish them, the participation of all members of the coalition was vital. Primarily, there was an emphasis on avoiding conflict. To confirm the mutual benefits it was necessary to minimize any focus on issues that would be divisive in the long term. Hewing to Winters doctrine rights would deviate from such predictable behavior. Insistence on the recognition of full Winters rights would have constrained the participation of the Navajo Tribe in the coalition. ${ }^{86}$

\section{B. The Navajo Indian Irrigation Project}

It is not sufficient to determine the manner in which the Navajos, or a similarly situated Indian tribe, participates in the bargaining process. For it may well be the case that participation is apparent rather than real, that the ultimate distribution of resources will be a function of power in the society rather than a function of participation in the process of decision-making or the manipulation of a legal right. In the study of the Navajo Generating Station, an attempt was made to look at the pattern of participation. From that perspective, it was possible to view the tribe as a ratifier rather than a bargainer. In the case of the Navajo Indian Irrigation Project, the trappings of actual participation were more in evidence. Indeed, in the case of NIIP (as the project is known), enough time has passed so that problems of imple-

86. The likelihood that this would have been the outcome was dramatically illustrated a few months after passage of the 1968 resolution. DNA, an OEO legal services program, established several years before, published a written statement and a brief concerning the Winters implications of the 1968 transaction. As opposed to the tribe, DNA as an institution was not nurtured in a tradition of mutual accommodation. Unlike all previous presentations, DNA reviewed the status of the tribe's water rights under the Winters doctrine with special attention to the implications of Arizona $\%$. California. The stress was on the continuing undefined right and the need for time for the tribe to evaluate the right in terms of the benefits from the construction of the plant at Page. The reaction of all the parties, including the tribe, was to exclude the offending parties from the decision making process. In this instance, the DNA was depicted as "interfering" and "causing a helluva turmoil among a lot of innocent people." Two strategies were employed by the anti-DNA group to dampen conflict: (1) to deny flatly that the Winters doctrine was involved in any way in Resolution CD-108-68 and the pending resolution and (2) to restrict severely the implications or interpretations of the Winters doctrine.

Note the following statements by a member of the Navajo Tribal Council:

$[T]$ he federally supported agency, DNA, are now interfering with the Navajo Tribe's governing body and officials. . . But here we are, the Navajo Tribal Council, representing our Navajo Tribe and trying to do what is right and trying to make use of our water rights by getting some revenue, get money from it and make use of it. Why should the DNA representatives try to interfere with what we are trying to do for the Navajo Tribe and trying to utilize our water rights in order to get revenue.

Navajo Tribal Council 198, June 3, 1969. 
mentation of the bargain can be discerned. Like the Navajo Generating Station episode, the history of the Navajo Indian Irrigation Project provides data for assessing the meaning of the Winters rights.

\section{The Bargaining Process}

The initial boundaries of the Navajo Reservation were created by treaty in 1868 on land encompassing a ștretch of the San Juan River, a tributary of the Colorado. When the utility of the water in the Colorado River system was being parceled out between the states in the 1922 and 1948 compact negotiations, however, the Navajos were not invited to sit at the bargaining table. It was assumed that their rights were protected by federal representatives and by the disclaimer clauses in the compacts. Non-Indians avoided consultation with the tribe partly because they viewed tribal sovereignty as mythological and tribal entities as existing more for purposes of education and internal tribal stability than for purposes of resource management and relationship with other governments. Indeed a formal tribal government did not exist on the reservation until shortly after the 1922 Compact. Moreover, at the time of the Upper Basin compact negotiations, the clear trend of federal Indian policy was toward the destruction of tribal political entities and the ultimate amalgamation of Indian communities into the states in which they were situated. The states involved had also set to work through their new Upper Colorado River Commission to put together a package of public works projects-collectively known as the Colorado River Storage Project (CRS)-which would provide benefits for each state.

Unlike the experience with the Navajo Generating Station, Navajo interest in the allocation of public works projects and their impact on Colorado River entitlements was expressed early in the deliberations. In 1948, the Navajo Tribal Council (NTC), aware of the emerging competition, requested the prompt development of irrigation projects to use San Juan River water and urged Congress not to approve any other uses of San Juan River water without the full protection of Navajo water rights. ${ }^{87}$ By the end of 1950, the joint efforts of the Bureau of Indian Affairs and the Bureau of Reclamation produced an interim planning report favoring construction of a storage facility and an irrigation project for the Navajos. ${ }^{88}$ New Mexico objected to the planning report, claiming that the only way the "legitimate needs" of New Mexico could be fulfilled would be for the report to include competing non-Indian projects for "concurrent authorization," including a San JuanChama project which would divert headwaters of the San Juan system across

87. Navajo Tribal Council, Resolution, December 8, 1948.

88. U.S. Dep't of the Interior, Regional Director's Report of December 1950 on Colorado River Storage Project and Participating Projects, Upper Colorado River Basin, in H.R. Doc. No. 364, 83d Cong., 2d Sess. 59-87 (1954). 
the divide into the Rio Grande River system which serves Albuquerque. ${ }^{89}$

In the spring of 1951, after federal and state representatives had spent time exploring possible formulas for accommodating projects on both sides of the divide, the Navajo Tribal Council requested an "active voice in the negotiations and in the selection of project sites." 90 NTC representatives and consultants began to participate directly in planning meetings and conferences. ${ }^{91}$

Soon it became clear that the states wanted the acreage and water figures fixed for the Navajo project. The Navajo Tribal Council was told that approval by the states of the irrigation project would depend on its size. ${ }^{92}$ The impression was conveyed that the conflict within New Mexico was delaying the Upper Colorado River Storage Project proposal. The Tribal Council chairman displayed an acute awareness of the political necessity of compromise: "If we are going to use all the water of the River . . . we will never have a project." ${ }^{\text {"93 }}$ Another councilman mused, "We will never see the water again if it goes over the mountain." 94 The council was being cautiously prepared for the likelihood of compromise both by its own attorney and a BIA attorney. ${ }^{95}$

Early in 1952, the Navajo Tribal Council met and resolved that it wanted an irrigation project with a net area of 122,000 acres and a preferential right to divert and use 610,000 acre-feet of water annually to supply such a project. The council also asserted that it had "a prior and preferential right to all of the waters of the San Juan River and its tributaries for use on the Navajo Tribal lands."96

89. Letter from John Bliss, State Engineer of New Mexico to Oscar Chapman, Secretary of the Interior, June 12, 1951, in id. at 307. It was assumed at this time that New Mexico's 11.25 entitlement under the 1949 Compact represented about 838,000 acre-feet of water and that, after deducting reservoir losses and depletions for authorized or existing irrigation projects, approximately 600,000 acre-feet was available for future development. U.S. Dep't of the Interior, Report of the Technical Comm. on Use of Waters of San Juan River in New Mexico, in State EngineER of New Mexico, a Review of the San Juan River Problem in New Mexico 20 app. IV, item 1 (1953). New Mexico was purporting to assert its control over these unappropriated waters as trustee on behalf of the public.

90. Id. at 21. See generally Lawson, The Navajo Indian Irrigation Project: Muddied Past, Clouded Future, 9 THE Indian Historian 19 (1976).

91. Within a few months the Navajo Tribal Council consultant was speaking in terms of a 118,000 acre, gravity-flow irrigation project for the Navajos and was confirming the water supply projections of federal and state staff people which indicated that the expected water shortages from all of the proposed New Mexico projects would be tolerable for such an irrigation project. See H. Person, Report on Potential Irrigation Development on Navajo Indian Reservation in San Juan River Basin 5 (1951); Statement of H.T. Person, Navajo Tribal Council, Minutes of Meeting, August 22, 1951.

92. Statement made by J.R. Riter, Navajo Tribal Council, supra note 9 , at 59 .

93. Id. at 56 .

94. Statement by Sam Gorman, id. at 54 .

95. Statements by Norman Littell and H.T. Person, id. at 62-63.

96. Navajo Tribal Council, Resolution No. CJ-4-52, January 18, 1952. The land reserved for the Navajos by the Treaty of 1868 encompasses a significant stretch of the San Juan River. 
Navajo participation was not only early but constituted an effective determinant of the structure of the arrangement among the competing political interests. Rather than object totally to a Navajo storage and irrigation project, New Mexico sought to have the Navajo project linked to a controversial San Juan-Chama diversion project through concurrent authorization. Other Upper Basin states indicated that their support of a Navajo project would be forthcoming if, in the process, Navajo claims to the tributaries would be limited and defined. Furthermore, it became clear that bargaining for support would not only involve the quantity of the Navajo right, but also its allocation in time of shortage. Indeed, in 1952 and 1953 negotiations almost ceased because of the sharing of shortage issue. All the Upper Basin states had an interest in a resolution of the conflict, and the Navajo Tribe perceived that it shared this interest.

The stalemate over the San Juan River projects was to continue, however, and was memorialized in the 1956 enactment of the Colorado River Storage Project Act. The Navajo Indian Irrigation Project and the San Juan-Chama Project were listed as "priority planning" projects in the Act, ${ }^{97}$ but were not authorized. Planning reports on these projects had been prepared in 1955 but departmental approval had been withheld pending resolution of the conflicting water use claims concerning the San Juan. For the remainder of 1956 and most of 1957, the competition between the east slope and west slope in New Mexico continued as each side reviewed its negotiating position and claims. In early 1957, Navajo tribal leadership began to support a proposal for a smaller irrigation project on higher quality crop land, a plan that would necessarily free a greater quantity of water for industrial use.

In late 1957, an important series of meetings was held, involving representatives of the Navajo Tribal Council, the New Mexico Interstate Stream Commission, and the BIA, relating to a draft bill for the simultaneous authorization of the Navajo Indian Irrigation Project (NIIP) and the San JuanChama Project (SJCP). The New Mexico Interstate Stream Commission approved the draft bill in mid-October ${ }^{98}$ and the Navajo Tribal Council adopted a resolution approving that bill on December $12,1957 .^{99}$ The draft bill provided for a sharing of shortages by NIIP and SJCP proportionate to their respective diversion requirements, and thereby called for a compromise of the 1868 water right priority date enjoyed by the Navajos. Several reasons for the compromise were presented to the Navajo Tribal Council by the tribal attorney, the consulting engineer, the BIA land operations engineer, and the State Engineer of New Mexico.

The tribal attorney explained that in time of water shortage under west-

97. Act of April 11, 1956, ch. 203, 70 Stat. 105, as amended, 43 U.S.C. $\$ 620$ (1970).

98. New Mexico Interstate Stream Comm'n, Resolution of October 17, 1957.

99. Navajo Tribal Council, Resolution No. CD-86-57, December 12, 1957. 
ern water law, a prior right carries with it the right to use the water to the exclusion of others, if need be. He stated that under the Winters doctrine, the priority date is the date the reservation is established. He then told the Navajo Tribal Council that there were several reasons why he was commending the sharing-of-shortages provision of the draft bill to them: ${ }^{100}$

[T] he first one is if the irrigation had first priority and got a full supply of water, even in years of shortage, the people who come in later, meaning the industrial users, would not get any water at all some years. What would happen? You would not get any industrial,users. If they could not depend on the water supply, they would not come in. You would not get industrial development. Industrial development I think, and I believe you agree with me, is just as important to the Navajo people as irrigation, maybe more so, so if the Navajo Tribe were to insist on first priority on irrigation projects, it would be killing off all the industrial jobs that the Navajos would otherwise get. It would be killing off the Utah Construction Project that we have all worked so hard for. The next reason is if we did not have this Section in the Bill, we would never get through Congress. If this were not in the Bill, the only project that would be feasible would be irrigation projects. The TransMountain and industrial development would not be feasible. They are reimbursable projects. They help to pay for Government work in New Mexico. If this were left just as this, it would just be a grant to the Navajo Tribe and the people from New Mexico would not support it and the Congressional delegates would not support it and we would not get anything.

The consulting engineer applied flow records for the 1927-1954 period to two alternatives: one that subordinated industrial and municipal uses to NIIP and SJCP and another that equated all those uses. He concluded that the shortages NIIP would have experienced over that period if it had no superior priority would have been sporadic and tolerable. ${ }^{101}$

The Navajo Tribal Council approved the draft bill containing the provision whereby all but preexistent users would share shortages proportionately. ${ }^{102}$ The Navajos were willing to sacrifice the priority of their water right for such anticipated benefits as industrial development and a heavily subsidized irrigation project. Thus, by 1958, a "horse trade" had been made.

In mid-June $1962,{ }^{103}$ Congress finally authorized construction of the

100. Navajo Tribal Council, Minutes of Meeting 68-69, December 11, 1957.

101. Id. at 75-76.

102. Navajo Tribal Council, supra note 99.

103. Between 1958 and 1962 Navajo and non-Indian interest groups from New Mexico had jointly appeared before congressional committees and lobbied for authorization of the New Mexico projects. Various authorization bills had received favorable treatment in the Senate but were repeatedly tied up in the House Committee on Interior and Insular Affairs, largely due to the opposition of California and Colorado representatives. California interests opposed the projects, as they had the overall Colorado River Storage Project, on the grounds that it was financially unsound. Representative Wayne Aspinall of Colorado, who was pushing for reclamation projects within Colorado on the Animus and La Plata, which are tributaries of the San Juan River, was concerned that the New Mexico projects might compete for the same water supply as those Colorado projects. During the legislative deliberations on the NIIP project, Aspinall made a record several times for the limitation of Navajo water claims. E.g., Hearings 
NIIP and San Juan-Chama projects. ${ }^{104}$ After almost a century of promises and a decade of active promotion, a largescale Navajo irrigation project was approved-but was far from built.

The 1962 Act authorizing the Navajo Irrigation Project seemed to culminate the Navajo bargaining effort. An unquantified Winters right, with all its uncertainties, had been converted to the promise of water works that could be of use to the Navajo people. Something was surrendered in terms of the Navajo's ultimate claim-compromise of a priority which probably would have made shortage-sharing unnecessary-in exchange for a promise of substantial federal funds to develop a portion of the Navajo economy that was desperately in need of nourishment. Bargaining seemed effective. The Navajos had seemingly employed the Winters right as a weapon, foreclosing transbasin diversion of water from the Colorado River system until a substantial benefit had been conferred on the Navajo people. By working through a national political forum, the Navajos could gain non-regional support for their position. And when it appeared that there was independent support for the Navajo project, the other regional participants in the coalition embraced it as enhancing the political strength of their collective approach to Congress.

The Navajo Indian Irrigation Project also represents a diligent effort by the Bureau of Indian Affairs and the tribe itself toward more active participation in the allocation of water resources and the federal largess. The period prior to 1962 was filled with study and analysis of alternate positions on the shape of such an irrigation project. And yet, more than a decade later, there are serious doubts about the basic premises of the project and the likelihood of ultimate success. The project was portrayed to Congress as one that would foster small farm agriculture on the eastern portion of the Navajo

on H.R. 2352, H.R. 2494, छ S. 72 Before the Subcomm. On Irrigation and Reclamation of the House Comm. On Interior and Insular Affairs, 86th Cong., 2d Sess. 70 (1960); Hearings on H.R. 2552, H.R. 6541, E S. 107 Before the Subcomm. on Irrigation and Reclamation of the House Comm. on Interior and Insular Affairs, 87th Cong., 1st Sess. 22, 30-31, 33, 56-57 (1961).

104. Act of June 13, 1962, Pub. L. No. 87-483, 76 Stat. 96, as amended, 43 U.S.C. $\$ \S 615,620$ (1970); Act of Sept. 25, 1970, Pub. L. No. 91-416, 84 Stat. 867 (codified in 43 U.S.C. $\$ 615$ (1970)). The Act of 1962, among other things, authorized a maximum of $\$ 135$ million for the Secretary of the Interior to "construct, operate, and maintain the Navajo Indian irrigation project for the principal purpose of furnishing irrigation water" to about 110,630 acres, at an average annual diversion of 508,000 acre-feet. Liability for repayment of construction costs is to be "within the capability of the land to repay," and is to be charged as liens against the land, conditionally payable only if and when the land passes out of Indian status. Section 2 incorporated section 4(d) of the Act of April 11, 1956, ch. 203, 70 Stat. 107, which in turn subjects Indian lands to the Act of July 1, 1932, ch. 369, 47 Stat. 564. The Secretary of the Interior is directed to declare a trust over certain federally owned land to the east of the reservation for inclusion in the project, upon payment by the Navajos of the full appraised value. The Act also authorizes the acquisition of other land suitable for the project and permits it to be held in trust status as well. The Secretary is authorized to include municipal and industrial capacity in the NIIP system. Water use is not to occur without approved contracts and the contracts must make provision for the sharing of shortages. Before entering into contracts the Secretary must take into account the diversion requirements of NIIP and SJCP. 
reservation. In many ways, the Project had at its heart a sense of the Navajo people and the future development of the land that may have been erroneous. In terms of cost to the nation of the implementation of the project, and in terms of per family benefits to the Navajo people, the Navajo Indian Irrigation Project has been open to increased critical analysis. In addition, the national implementation of the bargain is itself questionable. Federal support for the project has been slow and uneven while federal support for its exchange-counterpart, the San Juan-Chama Project, has moved steadily ahead to completion. Both of these aspects-the cultural premises of the bargain and its implementation by Congress-must be examined to understand the career of the Winters right.

\section{The Agricultural Premise}

One hypothesis of Jorgensen ${ }^{105}$ and others is that the reservation is a satellite of the metropolis, that its resources will be diverted primarily for the use of the dominant culture and the benefit of more powerful interests within that culture. The underlying planning and hope of the Navajo Indian Irrigation Project clearly sought a different objective. Winters rights were to be utilized essentially to achieve a goal harmonious with the Winters case itself. In a classic Winters sense, arid land would be irrigated and Navajo families would prosper thereby. Limited Navajo irrigation development had existed in the vicinity of Shiprock since 1900 and various schemes for large-scale projects had been entertained for fifty years. But only with the pressure of trans-basin diversion and the need for a resolution of the Navajo claim was the possibility of farming development a real one. The water resource was finally to be turned inward, finally to assist in achieving the kind of self-contained community foreseen in the nineteenth century. The Navajos, with the assistance of the massive infusion of regulated water, would be enabled to make the culturally significant switch from a quasi-nomadic existence to a pastoral community. The virtue of the project, in terms of its theoretical basis, was that a natural resource that was appurtenant to the reservation would be converted to enriching the lives of the Navajos with minimum diversion to the external, settler society.

Between 1950, when the concept of the Navajo Indian Irrigation Project was formalized, and 1975, the ideas that were at the heart of the project seemed to dissolve. The Navajo Tribe has come to see the economic future of the reservation more in terms of industrial development than agriculture. And the tribe's perception of the appropriate utilization of the Winters right has altered accordingly. Moreover, there has been an increasing sense that the agricultural ideal of the nineteenth century is ill-suited to the current Navajo family. As the massive project is studied and restudied, corporate

105. J. Jorgensen, The Sun Dance Religion, Power for the Powerless (1972). 
agriculture more and more replaces the family farm as the preferred mode of use of the irrigated lands. Both of these tendencies yield results that are closer to the Jorgensen hypothesis, for the move toward industrialization and corporate farming implicates non-Navajo interests far more substantially in the Navajo economy.

In 1966, Secretary Udall asked the Bureau of Reclamation to reevaluate completely the irrigation project. The reevaluation was being prompted, in part, by "exciting new opportunities for industrial development."106

These include particularly the opportunity to use the coal resource of the Navajo Indian for steam generation of electric power and to develop related industries, including petro chemicals. Accordingly, we are not at all sure that it will be serving the Navajos well to dedicate all of their available water for agricultural purposes and by so doing foreclose possibilities for industrial and recreational development which would seem to offer more possibilities to advance the economic opportunities of the Tribe. I would like to emphasize that studies we will make are intended solely to assist the Tribe in making the best use of its water. Our studies are not intended in any way to affect the Tribe's entitlement to the water or the construction of those facilities that would be necessary for delivery.

The resulting Task Force for Reevaluation of NIIP met in the spring of 1966, after being instructed by the Commissioner of Reclamation to abide by the 508,000 acre-feet diversion and 254,000 acre-feet depletion figures in the reevaluation study, but to consider alternate sizes of $110,000,77,000$ or 62,000 acres for NIIP. ${ }^{107}$ A smaller NIIP could provide residual water, among other things, for thermal power and petro-chemical development. The Navajos generally were hostile to the idea of reevaluation in 1966 . Reportedly, they had first heard about the reevaluation in the newspapers. ${ }^{108}$ They were upset by an expression of personal opinion by the State Engineer of New Mexico to the effect that New Mexico wanted to put its water entitlement to economic use without unnecessary delay, and that if NIIP was not going to use its authorized amount, the "residual water" ought to be "returned to the pool at Navajo Reservoir, available for contract and allocated where those needs first arise whether they are on or off the reservation." ${ }^{109}$ The Navajos rejected an opportunity to designate a representative to serve on the reevaluation task force. While the subsequent report of the task force recommended that a full-sized NIIP project be continued, it included two significant caveats. First, it recognized that the future might hold other opportunities for resource development besides agriculture and

106. Letter from Stewart Udall to Clinton P. Anderson, February 16, 1966.

107. Letter from Floyd Dominy, Commissioner of Reclamation to Regional Director, Amarillo, Texas, March 29, 1977, in Navajo Tribal Council, Task Force for Reevaluation of Navajo Indian Irrigation, Minutes of Meeting, April 8, 1966.

108. Id. at 12-13.

109. Id. at 11 . 
that such development would require water. Second, the reevaluation accentuated a change in thinking relating to the developments of family farms in the project. Congressional committees previously had been told that approximately 1,200 family farms would be established, a plan that would be compatible with a standard BIA policy holding that the "development and extension of irrigation projects on Indian reservations are primarily for the benefit of resident reservation Indian families."110 The 1966 reevaluation study emphasized the necessity of recognizing that sociocultural differences between Indian and non-Indian farmers demanded "fresh thinking and perception" in the planning of NIIP farm development. ${ }^{111}$ The plans should be so compatible with the indigenous culture as to "avoid past pitfalls and failures in Indian irrigated farming," many of which were catalogued by the study. Farm development should proceed on the basis of creating large land blocks of 2,000 or 3,000 acres, within which assignments of varying sizes would be made to individual Navajo farms. Unassigned acreage could be "operated by a managed farm enterprise employing either Navajo laborers or the farmers and family members in the block." The major goal, however, ought to remain the "family farm." 112 This goal was to become more and more remote in the ensuing months and years. Less than a month after Secretary Udall approved the reevaluation study, the Commissioner of Indian Affairs disclosed further doubts as to whether irrigated agriculture, as nonIndians knew it, was culturally suitable for the Navajos. ${ }^{113}$ NIIP thereafter emerged as an agri-business development. ${ }^{114}$

110. Statement of Phileo Nash, B.I.A. Commissioner, in Hearings on H.R. 5279 Before a Subcomm. of the Senate Comm. on Appropriations, 88th Cong., 1st Sess. 107 (1963).

111. U.S. Dep't of the Interior, Bureau of Reclamation, Reevaluation Report Navajo Indian Irrigation Project, New Mexico, X-1 app. (1966).

112. Id. at $\mathrm{X}-16,18$.

113. Memorandum from Robert Bennett, B.I.A. Commissioner to Graham Holmes, Area Director, January 13, 1967.

114. In 1970 the Navajo Tribal Council created a tribal enterprise called Navajo Agricultural Products Industry (NAPI) to manage agricultural development on the Reservation, particularly within NIIP. This tribal enterprise approach had been used before with the Forest Products Industry and the Navajo Tribal Utility Authority. NAPI has a management board composed of Navajos and non-Indians with farming and reclamation experience. The board has been overseeing pilot projects and development plans for NIIP.

The Agricultural Experiment Station of the New Mexico State University has conducted agricultural studies related to NIIP. One 1972 study concluded that, due to a lack of experienced Navajo farmers, the tribal enterprise approach was preferable initially to 320 -acre individual farms. The study estimated that investment capital of $\$ 56.5$ million would be needed to develop the project on a tribal enterprise scale with a good mix of field, seed and vegetable crops, and livestock. It was predicted that federal assistance, over and above private financing, would be needed. No net expendable income could be expected until the fourth year (about $\$ 2$ million), thereafter it would rise to about $\$ 7.5$ million by the twelfth year. New Mexico State UNiversity, Agricultural Experiment Station, Alternative Form Organizational Structures for the Navajo Indian Irrigation Project 183, 188-95 (1972). This large-scale, agri-business farm unit approach to NIIP can be criticized for its apparent failure to take into account elements of the indigenous native culture and for its inability to provide incentives for individual 


\section{Implementing the Bargain}

The second major issue in Winters implementation relates to the process of federal financing of the works necessary for the Navajo project. In terms of understanding techniques for the resolution of Winters uncertainties, it is critical to appreciate the complexities that arise after a bargain is struck, the right is quantified, or there is congressional authorization for the project. Authorization is but the first step in the long journey to the completion of a federal water resource project. ${ }^{115}$ The real commitment of Congress comes when it backs up the authorization with the appropriation of money. To determine the implications of a bargain, one must look at the appropriation process as critically as at the original authorization. The Navajo Indian Irrigation Project, it will be recalled, was a bargained-for exchange for the San Juan-Chama diversion project. Both were concurrently authorized in the 1962 legislation, one to serve the Navajos and the other to supplement the water supply of the settler culture of New Mexico. The pattern of appropriations is instructive. In the case of NIIP, Congress met the 1962 authorization of $\$ 135$ million with appropriations of only $\$ 1.8, \$ 4.7$, and $\$ 6.5$ million for fiscal 1964, 1965, and 1966, respectively. ${ }^{116}$ San Juan-Chama, authorized for $\$ 85.8$ million by comparison, received approximately $\$ 1$ million more than this amount over the same three-year period. ${ }^{117}$ By the late $1960 \mathrm{~s}$, the splendor of the reclamation ethic had been tarnished and the Bureau of the Budget was ordering slowdowns on public works projects. An estimated two to three year delay in the water delivery schedule for NIIP resulted. ${ }^{118}$ NIIP was 16 per cent completed in 1969, whereas the San JuanChama Project was 57 per cent completed and on schedule; ${ }^{119}$ and the figures

\footnotetext{
Navajos. Concerns are being expressed that Navajo income and employment will not be adequately maximized.

115. See generally N. Ely, Authorization of Federal Water Projects (National Water Comm'n Legal Study No. 12, 1971).

116. See Statement of David F. Cargo, Governor of the State of New Mexico, in Hearings on H.R. 17619 Before a Subcomm. of the Senate Comm. on Appropriations, 91st Cong., 2d Sess. 4054 (1970)

117. $\$ 1.6$ million for Fiscal $1964 ; \$ 5.9$ million for Fiscal 1965 ; and $\$ 7.7$ million for Fiscal 1966. See Hearings on Public Works Appropriations for 1967 of the House Comm. on Appropriations, 89th Cong., 2d Sess. 410 (1966); Hearings on Public Works Appropriations for 1966 Before a Subcomm. of the House Comm. on Appropriations, 89th Cong., 1st Sess. 409 (1965); Hearings on Public Works Appropriations for 1965 Before a Subcomm. of the House Comm. on Appropriations, 88th Cong., 2d Sess. 422 (1964).

118. Exchange between Senator Carl Hayden and Robert Bennett, B.I.A. Commissioner, in Hearings on H.R. 9029 Before a Subcomm. of the Senate Comm. on Appropriations, 90th Cong., Ist Sess. 784 (1967).

119. Statement of Robert Bennett, B.I.A. Commissioner, in Hearings on H.R. 12781 Before a Subcomm. of the Senate Comm. on Appropriations, 91st Cong., 1st Sess. 166 (1969); see U.S. DEP'T of the Interior, Bureau of Reclamation, Project Data Sheet, UCRBF-San Juan Chama Participating Project, Colorado-New Mexico (1969), in Hearings on H.R. 14159 Before a Subcomm. of the Senate Comm. on Appropriations, 91 st Cong., 1st Sess. 2973 (1969).
} 
for 1970 were about 17 per cent and 65 per cent, respectively. ${ }^{120}$ Strong pleas to Congress on behalf of NIIP by members of the New Mexico delegation, the Governor, the State Engineer, and federal officials led to enactment of a 1970 law increasing the authorization ceiling for NIIP to $\$ 206$ million (1970 prices). ${ }^{121}$ However, appropriations remain well below that ceiling. As of 1975 a total of $\$ 86$ million had been appropriated for NIIP. ${ }^{122}$

Water has been scheduled for delivery on the first block of 10,000 acres in 1976. In March of 1975 the State of New Mexico, prompted by an unquantified water right claim of the Jicarilla Apaches, filed a lawsuit in state court to adjudicate water rights in the New Mexico stretch of the San Juan River system, ${ }^{123}$ putting at issue Navajo water rights in the San Juan. It is unclear to what extent the litigation will cause delays in funding or water delivery for NIIP. One recent analysis suggests that over-contracting of supplies now poses the possibility of water shortages within the New Mexico portion of the San Juan system and could reduce deliveries to NIIP. ${ }^{124}$

Certainly, numerous reasons can be cited for the differential treatment of the two projects and the delay in appropriations for the Navajo Indian

120. Statement of Charles Corke, in Hearings on H.R. 17619 Before a Subcomm. of the Senate Comm. on Appropriations, 91 st Cong., 2d Sess. 2021 (1970).

121. 43 U.S.C. $\$ 61500(1970)$.

122. The following NIIP appropriation figures were supplied by Harold Boyd, Assistant Project Manager for NIIP Construction, Bureau of Reclamation, Farmington, New Mexico, April 21, 1975.

$\begin{array}{cc}\text { Year } & \text { Actual Appropriations } \\ 1963 & 300,000 \\ 1964 & 1,800,000 \\ 1965 & 4,700,000 \\ 1966 & 6,500,000 \\ 1967 & 6,498,000 \\ 1968 & 5,300,000 \\ 1969 & 3,548,000 \\ 1970 & 5,300,000 \\ 1971 & 3,800,000 \\ 1972 & 8,900,000 \\ 1973 & 10,500,000 \\ 1974 & 14,000,000 \\ 1975 & 15,200,000 \\ & \$ 86,346,000\end{array}$

123. State of New Mexico, ex rel. State Engineer v. United States, Civil No. 75-184 (D.N.M., filed March 13, 1975).

124. See R. Hughes, Gasification and the NIIP: A Study of Upper Basin Water Availability in New Mexico, 9 (undated and unpublished paper on file with the DNA).

Considering the diversion requirement of $370,000 \mathrm{a}$ [cre] f[eet $] / \mathrm{yr}$, for the NIIP as presently conceived, the absence of any competent studies indicating return flow, the fact that the NIIP water contract will probably be the last San Juan water contract to come before Congress, and the stiff statutory prohibitions against operating the project so as to put New Mexico over its Article III Compact allocation, it is difficult to reach any other conclusion but that every new diversion of San Juan water in New Mexicoincluding particularly the water ear-marked for the gasification projects-will ultimately result in a severe reduction in the size of the NIIP. 
Irrigation Project. Among those reasons were changed technology in the projected irrigation system, yielding some dispute about the nature of the diversion right for NIIP, ${ }^{125}$ and some lingering uncertainty about the basic purpose and cost-effectiveness ${ }^{126}$ of the project itself. But an alternative explanation, consistent with the course of events, lies in the reduced power of the Navajo Tribe after its bargaining advantage had been relinquished. The uncertainties of the Winters right could be employed to hold hostage a transbasin diversion. But once the Winters right was compromised and the San Juan-Chama diversion project was authorized, the weight of the Navajo stance diminished. The appropriation process, the ultimate test of strength in Congress, was one in which the mythology of the family farm and the utility of the NIIP as a mechanism for clearing other projects was far more closely scrutinized. Perhaps only as the project more closely approximates the Jorgensen model-only as the reservation land becomes more significantly a source for non-Navajo development-will NIIP progress toward completion.

\section{Conclusion}

Rights can be weapons, but their potency rests on a number of factors. Although elaboration of the legal issues inherent in the Winters doctrine is essential to an understanding of its implications, the extent to which tribes can deploy its potential rests heavily on congressional support, judicial constancy, changing conceptions of reservation purposes and goals, developmental alternatives, and the costs to all parties of striking a bargain. No less important is the role of intergovernmental bodies entrusted with the power of fashioning resource allocation decisions. The fact that the Navajo were not represented in the formulation of the Colorado River Compacts or were not before the interstate stream commissions, and the fact that consortia of power companies have close links to state governments but not to the tribes

125. Originally planned as a gravity-flow system, NIIP was expected to result in a net depletion of 254,000 acre-feet in a return flow of an equal amount. Sprinkler irrigation now is planned which will reduce the diversion from 508,000 acre-feet to 370,000 acre-feet, causing a net depletion of 230,000 acre-feet and returning 140,000 acre-feet to the San Juan. The issue accentuated by this change was whether the Navajo entitlement is 508,000 acre-feet, irrespective of the amount of net depletion, or 254,000 acre-feet, in net depletion. Late in 1974, the Deputy Solicitor of the Department of the Interior ruled that the tribe is entitled to the smaller net-depletion amount. Navajo Indian Irrigation Project-Water Entitlement of Navajo Tribe, memorandum from David E. Lingren, Deputy Solicitor to John C. Whittaker, Under Secretary of the Interior, December 6, 1974.

126. For example, Senator Bible of Nevada offered the suspicion in 1970 that NIIP was a "totally marginal project." Hearings on H.R. 17619, supra note 116, at 2022. Congressman Hosmer of California had argued in 1955 that if the $\$ 200,000$ expected to be spent in bringing water to each Navajo family farm in NIIP were invested instead at a five per cent yield, the income would double that produced by farming. Hearings on H.R. 270, H.R. 2836, H.R. 3383, H.R. 3384, E H.R. 4488 Before the Subcomm. on Irrigation and Reclamation of the House Comm. on Interior and Insular Affairs, 84th Cong., 1st Sess. 234 (1955). 
involved, have a deep effect on the way Winters rights are subject to bargain and negotiation. Similar importance attaches to the fact that the Bureau of Indian Affairs, as operating trustee, has been unable to supply the expertise necessary to counter the Bureau of Reclamation's assessments of technical alternatives. Often non-Indians simply postpone the resolution of Indian rights, hoping that they will disappear or that courts will not interfere with a developed pattern of resource reliance. Even if a compromise is reached, failure to obtain congressional appropriations may undermine the bargain.

The stark truth of the matter is that, beginning at the turn of the century, the offices and powers of national government were marshalled to plan, construct, and finance non-Indian agricultural development in the West, and nothing comparable was done for the Native American. Conveniently, this disparity could be rationalized, in part, by the assumption, grounded in the Winters doctrine, that early-priority Indian water rights were unaffected by non-Indian development and could successfully be exercised at any point in time, without regard to intervening non-Indian development. As the resource demands of urban areas increase, and reservations are mined or industrialized to meet these demands, ${ }^{127}$ the uncertainties of the Winters doctrine provide a context in which legal rights become the subject of complex negotiation whose purpose and outcome vary in accordance with a broad range of social, economic, and political factors.

127. The study, L. Robbins, The Impact of Power Developments on the Navajo Nation (Lake Powell Res. Project Bull. No. 7, 1975) indicates that energy-related industrialization on the Reservation is not significantly improving the economic condition of the Navajo people as a whole. 